\title{
Distribution and Quantity of Root Systems of Field-Grown Erianthus and Napier Grass
}

\author{
Nobuhito Sekiya $^{1^{*}}$, Fumitaka Shiotsu ${ }^{2}$, Jun Abe ${ }^{1}$, Shigenori Morita ${ }^{1}$ \\ ${ }^{1}$ Graduate School of Agricultural and Life Sciences, The University of Tokyo, Tokyo, Japan; ${ }^{2}$ College of Agriculture, Ibaraki Uni- \\ versity, Ibaraki, Japan. \\ Email: "kapinivilage@yahoo.co.jp
}

Received August $16^{\text {th }}, 2013$; revised September 21 $1^{\text {st }}, 2013$; accepted October $22^{\text {nd }}, 2013$

Copyright (C) 2013 Nobuhito Sekiya et al. This is an open access article distributed under the Creative Commons Attribution License, which permits unrestricted use, distribution, and reproduction in any medium, provided the original work is properly cited.

\begin{abstract}
Cellulosic bioethanol produced from non-edible plants reduces potential food-fuel competition and, as such, is receiving increasing attention. In the raw material production of cellulosic bioethanol, the aboveground biomass of plants is entirely harvested; consequently, the plant roots represent the major source of organic matter incorporated into the soil. We selected Erianthus and Napier grass as the raw materials for cultivation in Asia. However, information about whether these 2 species provide sufficient root volume to sustain soil fertility is limited. Therefore, we examined the spatial distribution of the roots of these 2 plants, and quantified root mass and length. Erianthus and Napier grass were either grown in fields or greenhouses in Tokyo (Japan) and Lampung (Indonesia), and then their roots were exposed from adjacent soil profiles. Both species developed large, deep roots, penetrating $2.0-2.6 \mathrm{~m}$ deep into the soil. Root depth indexes showed that the roots of both species penetrated much deeper into the soil compared to monocot crop species, being more comparable to dicot species. Erianthus developed a root mass and length of $384-850 \mathrm{~g} \cdot \mathrm{m}^{-2}$ and $28.8-35.8 \mathrm{~km} \cdot \mathrm{m}^{-2}$, while the values for Napier grass were $183-448 \mathrm{~g} \cdot \mathrm{m}^{-2}$ and $15.6-43.6 \mathrm{~km} \cdot \mathrm{m}^{-2}$, respectively. These values exceeded the maximum values previously recorded for common crop species. Our study confirmed that Erianthus and Napier grass develop deep root systems, with substantially large biomass; hence, we suggest that both plants supply root biomass in large quantities, representing possible major sources of soil organic matter.
\end{abstract}

Keywords: Erianthus arundinaceus; Pennisetum purpureum; Profile-Wall Method; Root Depth Index; Root Length Density; Root Weight Density

\section{Introduction}

Although bioethanol is a promising alternative fuel that is viewed as a potential countermeasure to global warming, there are concerns that the rapid increase in global bioethanol production is leading to possible competition with food production. In comparison, cellulosic bioethanol produced from non-edible plants reduces potential food-fuel competition and, as such, is receiving increasing attention; hence, if such plants are grown on marginal non-arable lands, farmland soils are not required [1]. However, questions have been raised regarding the sustainability of material plant production [2]. In food crop production, plant residues are incorporated into soils after harvesting. In contrast, with cellulosic bioethanol production, the entire aboveground biomass is harvested. This practice might reduce soil fertility, and eventually

*Corresponding author. threaten the sustainability of the bioethanol industry.

A solution to this problem might lie in the "hidden half" of material plants, namely the roots. Within the framework of a project to select suitable bioenergy plants for cultivation in tropical and sub-tropical regions of Asia, our research group selected Erianthus arundinaceus (Erianthus) and Pennisetum purpureum (Napier grass) as raw materials for cellulosic bioethanol on the basis of their large shoot biomass and high tolerance to biotic and abiotic stresses [1,3,4]. However, published information about the root system of these 2 species is limited. These plants are expected to develop extensive root systems that mechanically support their large, heavy shoots, and exploit water and nutrients for vigorous growth. In general, roots exude organic substances, leading to the substantial accumulation of carbon in soils $[5,6]$. Moreover, root biomass produced during the plant growing period is expected to be far greater compared to 
standing roots for which dead roots are included in the same period $[7,8]$. Thus, the root biomass of plants, including dead roots and associated exudates, might provide sufficient organic matter for sustaining soil fertility.

This study aimed to collect basic information about the root systems of these 2 species, as a first step towards evaluating their contributions to soil fertility. Specifically, we aimed to 1) examine the root distributions, particularly rooting depth; and 2) quantify root mass and length parameters of Erianthus and Napier grass. We believe that the result of this study will contribute information about the mechanisms facilitating the vigorous growth of these 2 species under water and nutrient deficient conditions.

\section{Material and Methods}

Field and greenhouse experiments were conducted in the Institute for Sustainable Agro-ecosystem Services (ISAS), Tokyo, Japan $\left(35^{\circ} 43^{\prime} \mathrm{N}, 139^{\circ} 32^{\prime} \mathrm{E}\right)$ from June 2008 to October 2012. The soil at this site is volcanic ash of the Kanto loam type (Humic Andosol). A parallel experiment was conducted in a field belonging to the Toyota Bio Indonesia (TBI), Lampung, Indonesia $\left(5^{\circ} 23^{\prime} \mathrm{S}, 105^{\circ} 22^{\prime} \mathrm{E}\right)$ from May 2010 to August 2012. This location was selected based on the results of a previous study [9]. The soil here is red-yellowish podzolic type. Details about the plant growth management used in each experiment are shown in Table 1.
The shoots of selected plants were harvested after measuring plant height (Height) and stem number (Stem). The shoots were then dried at $80^{\circ} \mathrm{C}$ for $72 \mathrm{~h}$, and weighed $(S W)$. A soil profile $(1-2 \mathrm{~m}$ long $\times 2 \mathrm{~m}$ deep) was exposed $0.1 \mathrm{~m}$ away from a selected plant by digging a trench $(1-2 \mathrm{~m}$ long $\times 1 \mathrm{~m}$ wide $\times 2 \mathrm{~m}$ deep $)$ mechanically or manually at a right angle or in parallel to a row (Figures 1(a), (b)). Soil cores $(50 \mathrm{~mm}$ diameter $\times 51 \mathrm{~mm}$ long) were sampled from a profile by inserting stainless steel cylinders at $0.1 \mathrm{~m}$ or $0.2 \mathrm{~m}$ spacing (Figure 1(c)). A larger soil core $(50 \mathrm{~mm}$ diameter $\times 600 \mathrm{~mm}$ long) was collected from the bottom of the trench, by inserting a liner sampler DIK-110C (Daiki Rika Kogyo, Japan) at a right angle to the trench bottom (Figure 1(d)). Thereafter, roots were gently washed under running water until free of soil using a $0.5-\mathrm{mm}$ sieve. The cleaned roots were preserved in $70 \%$ ethanol. Then, the roots were spread on a transparent tray, without overlapping, and digitized images were obtained using a scanner with 300 dpi and 256 grey-scales. Root length $(R L)$ was determined by using WinRHIZO Basic LA 2400 (Regent Instrument, Canada). After scanning, roots were dried at $80^{\circ} \mathrm{C}$ for $48 \mathrm{~h}$, and weighed. Root length and weight density ( $R L D$ and $R W D$ ) were calculated by dividing each parameter with a volume of soil core. The root depth index $(R D I)$ indicates the mean depth of roots [10], and calculated by first summing $R L$ for each soil layer. Then, the percentage $R L$

Table 1. Overview of the field and greenhouse experiments carried out in Tokyo and Lampung.

\begin{tabular}{|c|c|c|c|c|c|c|c|c|}
\hline Site & Plant & Nursery plant & Plot & Spacing & Planting date & Cutting date & Fertilizer & Measurements \\
\hline \multirow{4}{*}{$\begin{array}{c}\text { Field } \\
\text { (Tokyo) }\end{array}$} & Er & $\begin{array}{c}0.9 \text { - } 1.1 \mathrm{~m} \text { height } \\
4 \text { - } 6 \text { stems } \\
2 \text { - } 3 \text { leaves stem }{ }^{-1}\end{array}$ & $\begin{array}{l}3 \mathrm{~m} \times 4 \mathrm{~m} \\
(1 \mathrm{plot})\end{array}$ & $\begin{array}{c}3 \text { rows }\left(2 \text { hills row }{ }^{-1}\right) \\
2.0 \mathrm{~m} \text { between rows } \\
3.0 \mathrm{~m} \text { between hills }\end{array}$ & Jun 6,2008 & $\begin{array}{l}\text { Apr. 2, } 2009 \\
\text { Mar. 31, } 2010 \\
\text { Mar. 30, } 2011\end{array}$ & & $\begin{array}{l}2 \text { hills in the } \\
\text { middle row } \\
\text { (Apr. 2011) }\end{array}$ \\
\hline & Er & $\begin{array}{l}0.4-0.5 \mathrm{~m} \text { height } \\
30-40 \text { stems }^{-1} \\
3-5 \text { leaves stem }\end{array}$ & $\begin{array}{l}6 \mathrm{~m} \times 2 \mathrm{~m} \\
(1 \mathrm{plot})\end{array}$ & $\begin{array}{c}3 \text { rows }\left(6 \text { hills row }{ }^{-1}\right) \\
1.0 \mathrm{~m} \text { between rows } \\
1.0 \mathrm{~m} \text { between hills }\end{array}$ & & Jun. 20, 2011 & & \\
\hline & $\mathrm{Na}$ & $\begin{array}{c}0.5-0.7 \mathrm{~m} \text { height } \\
1 \text { stem } \\
3-5 \text { leaves stem }^{-1}\end{array}$ & $\begin{array}{c}6 \mathrm{~m} \times 2 \mathrm{~m} \\
(1 \mathrm{plot})\end{array}$ & $\begin{array}{c}3 \text { rows }\left(13 \text { hills row }{ }^{-1}\right) \\
1.0 \mathrm{~m} \text { between rows }\end{array}$ & May 31, 2010 & Jun. 21, 2011 & $\begin{array}{c}\mathrm{N}: 7.2 \mathrm{~g} \cdot \mathrm{m}^{-2} \\
\mathrm{P}_{2} \mathrm{O}_{5}: 10.8 \mathrm{~g} \cdot \mathrm{m}^{-2} \\
\mathrm{~K}_{2} \mathrm{O}: 9.6 \mathrm{~g} \cdot \mathrm{m}^{-2}\end{array}$ & $\begin{array}{l}2 \text { hills in the } \\
\text { middle row } \\
\text { (Jun. 2011) }\end{array}$ \\
\hline & $\mathrm{Su}$ & $\begin{array}{l}0.2-0.3 \mathrm{~m} \text { height } \\
1 \text { stem } \\
2-3 \text { leaves stem }\end{array}$ & $\begin{array}{l}6 \mathrm{~m} \times 2 \mathrm{~m} \\
(1 \mathrm{plot})\end{array}$ & $0.5 \mathrm{~m}$ between hills & & Jun. 23, 2011 & $\begin{array}{l}\text { Before planting and after } \\
\text { each cutting }\end{array}$ & \\
\hline \multirow{2}{*}{$\begin{array}{l}\text { Green } \\
\text { house } \\
\text { (Tokyo) }\end{array}$} & Er & $\begin{array}{l}0.2 \text { - } 0.4 \mathrm{~m} \text { height } \\
2 \text { - } 4 \text { stems } \\
4 \text { - } 6 \text { leaves stem }{ }^{-1}\end{array}$ & $\begin{array}{l}6 \mathrm{~m} \times 8 \mathrm{~m} \\
(3 \text { plots })\end{array}$ & $\begin{array}{l}8 \text { rows }\left(4 \text { hills row }{ }^{-1}\right) \\
1.0 \mathrm{~m} \text { between rows } \\
2.0 \mathrm{~m} \text { between hills }\end{array}$ & Jun 9, 2010 & $\begin{array}{l}\text { Mar. 14, } 2011 \\
\text { Sep. 29, } 2011 \\
\text { Oct. } 15,2012\end{array}$ & & \multirow{2}{*}{$\begin{array}{l}1 \text { hill in } \\
\text { each plot } \\
\text { (Oct. 2012) }\end{array}$} \\
\hline & $\mathrm{Na}$ & $\begin{array}{c}0.4-0.5 \mathrm{~m} \text { height } \\
1-2 \text { stems } \\
6-8 \text { leaves stem }^{-1}\end{array}$ & $\begin{array}{l}7 \mathrm{~m} \times 6 \mathrm{~m} \\
(3 \text { plots })\end{array}$ & $\begin{array}{l}7 \text { rows }\left(15 \text { hills row }{ }^{-1}\right) \\
1.0 \mathrm{~m} \text { between rows } \\
0.5 \mathrm{~m} \text { between hills }\end{array}$ & May 30, 2011 & $\begin{array}{l}\text { Sep. } 22,2011 \\
\text { Oct. } 5,2012\end{array}$ & & \\
\hline $\begin{array}{c}\text { Field } \\
\text { (Lampung) }\end{array}$ & $\mathrm{Na}$ & $\begin{array}{l}0.1-0.2 \text { m stem } \\
\text { cuttings with } \\
1-2 \text { buds }\end{array}$ & $\begin{array}{c}30 \mathrm{~m} \times 50 \mathrm{~m} \\
(1 \mathrm{plot})\end{array}$ & $\begin{array}{l}1.0 \mathrm{~m} \text { between rows } \\
0.5 \mathrm{~m} \text { between hills }\end{array}$ & May 30, 2010 & $\begin{array}{l}\text { Oct. 25, } 2010 \\
\text { Oct. 24, } 2011 \\
\text { Mar. 1, 2012 } \\
\text { Aug. 27, } 2012\end{array}$ & $\begin{array}{c}\mathrm{N}: 30 \mathrm{~kg} \cdot \mathrm{ha}^{-1} \\
\mathrm{P}_{2} \mathrm{O}_{5}: 15 \mathrm{~kg} \cdot \mathrm{ha}^{-1} \\
\mathrm{~K}_{2} \mathrm{O}: 15 \mathrm{~kg} \cdot \mathrm{ha}^{-1} \\
\text { 0, } 1.5 \text { and } 3 \text { months after } \\
\text { planting and cutting }\end{array}$ & $\begin{array}{l}3 \text { hills in } \\
\text { the plot } \\
\text { (Aug. 2012) }\end{array}$ \\
\hline
\end{tabular}

Er: Erianthus, Na: Napier grass, Su: sugarcane. 


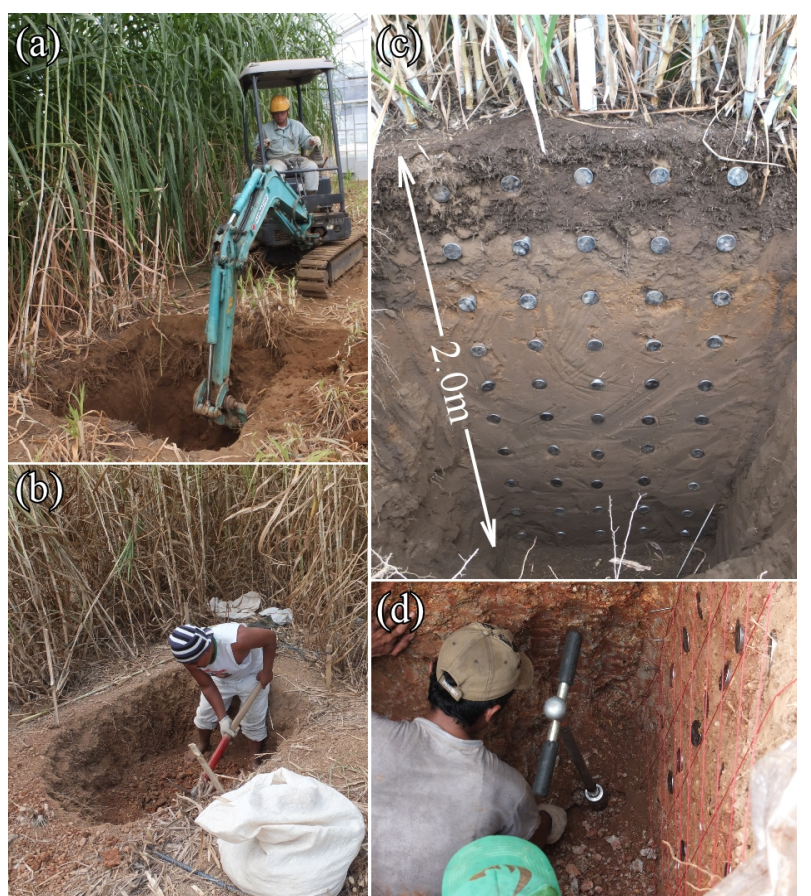

Figure 1. Root measurement method. A trench (1 - 2 m long $\times 1 \mathrm{~m}$ wide $\times 2 \mathrm{~m}$ deep) was excavated mechanically (a) or manually (b). Soil cores $(50 \mathrm{~mm}$ in diameter $\times 51 \mathrm{~mm}$ in length) were sampled from a profile $(1-2 \mathrm{~m}$ long $\times 2 \mathrm{~m}$ deep) by inserting stainless steel cylinders at $0.1 \mathrm{~m}$ or $0.2 \mathrm{~m}$ spacing (c). A larger soil core $(50 \mathrm{~mm}$ diameter $\times 600 \mathrm{~mm}$ long) was sampled from the trench bottom by using a liner sampler to investigate depths of 2.0 - $2.6 \mathrm{~m}$ depth (d).

in a layer compared to the whole 2-m sample depth was calculated (e.g., $a, b, c \cdots, t \%$ for $0-0.1,0.1-0.2,0.2$ $0.3 \cdots, 1.9-2.0 \mathrm{~m}$, respectively). These percentage values were then multiplied by the depth of the mid-position of the corresponding layer (e.g., $0.05 a, 0.15 b, 0.25 c \cdots$, $1.95 t$ ), summed (e.g., $0.05 a+0.15 b+0.25 c+\cdots+1.95 t$ ), and divided by 100 .

\section{Results and Discussion}

Erianthus and Napier grass developed large, deep root systems that penetrated the soil to a depth of $2.0-\mathrm{m}$ in all experimental plots (Table 2). Some roots were even found at $2.6 \mathrm{~m}$ deep. Previously, Erianthus has been mainly studied as a source of new genetic variation for sugarcane breeding [11]. To date, studies about the root system of Erianthus remain limited, except for a study by Tiwari (1986) [12] who measured root biomass in soil monoliths $(0.5 \mathrm{~m}$ long $\times 0.5 \mathrm{~m}$ wide $\times 0.6 \mathrm{~m}$ deep $)$, which were collected from a Himalayan grassland dominated by 3 grass species, including Erianthus rufipilus. The author estimated the belowground net primary production without differentiating Erianthus from the other 2 species. Thus, the current study is the first to describe the deep rooting characteristics of Erianthus. In contrast,
Napier grass has been extensively studied for fodder and other uses [13]. However, only a limited number of studies are available about its roots. Thus, some reports describe Napier grass as a shallow rooting species based on the visual observation of its extensive surface root system $[14,15]$, while others consider it a deep rooting species, based again on visual observations [16]. Recently, Ma et al. (2012) [17] reported that more than $80 \%$ of the root mass of hybrid giant Napier grass was found in soil depths of $0-0.25 \mathrm{~m}$ when evaluating soil to a depth of 1 $\mathrm{m}$, leading to the assumption that this plant is a shallow rooting species. In contrast, Knoll et al. (2012) [18] detected Napier grass roots at soil depths of $0.91-1.07 \mathrm{~m}$. The authors suspected that high rates of nutrient removal by Napier grass might be ascribed to its capacity to extract nutrient reserves in soils deeper than $1.0-\mathrm{m}$. However, the authors also stated that they were unable to examine how deep Napier grass roots extended, due to the sampling difficulty. The present study provides evidence supporting the hypothesis of Knoll et al. (2012) [18].

In this study, the depth of Erianthus and Napier grass root systems was confirmed with $R D I$ values (Table 2). $R D I$ is the weighted average of root depth in soils [10], which have been previously used to successfully screen deep rooting wheat cultivars in Japan [19]. This parameter has also been used to determine the root depths of different crop species. However, the RDI values obtained in these preceding studies were low, such as $0.06-0.12$ for wheat [10,19], $0.08-0.14$ for rice [20], $0.08-0.1$ for soybean [21], and $0.16-0.27$ for sugarcane [22]. In contrast, Erianthus and Napier grass had high RDI values, ranging from 0.34 to 0.79 and from 0.24 to 0.73 , respectively. Because previous studies investigated root distributions in shallow soil layers of $0.16-0.27 \mathrm{~m}$, the obtained $R D I$ values might increase if root penetration into deeper soil layers was investigated [23]. Therefore, we estimated the RDI values of some crop species using the root distribution data from deeper soil layers. The estimated $R D I$ values were 0.26 for wheat $(1.8 \mathrm{~m})$ [24], 0.27 - 0.29 for maize $(1.5 \mathrm{~m})$ [25], 0.19 for sorghum $(1.4 \mathrm{~m})$ [26], 0.17 for rice $(0.8 \mathrm{~m})$ [27], $0.16-0.36$ for sugarcane $(1.0-2.0 \mathrm{~m})[28,29], 0.34$ for oilseed rape $(1.8 \mathrm{~m})$ [30], 0.75 for soybean $(1.8 \mathrm{~m})$ [31], and $0.66-1.2$ for cotton $(1.8 \mathrm{~m})$ [32]. The values in parentheses indicate the soil depths investigated. The results indicate that monocots with fibrous root systems (i.e., wheat, maize, sorghum, rice, and sugarcane) have low $R D I$ values compared to dicots with primary root systems (i.e., oilseed rape, soybean, and cotton). Thus, Erianthus and Napier grass, which develop fibrous root systems, should be considered deep rooting species among monocot crop species, with their root depths being comparable to those of dicot crop species, which tend to develop deep rooting systems. 
Table 2. Various parameters that were measured for Erianthus (Er), Napier grass (Na), and sugarcane (Su) grown in the field

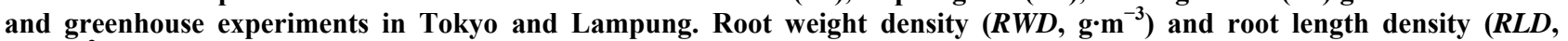
$\mathrm{km} \cdot \mathrm{m}^{-3}$ ) were measured at each $0.4-\mathrm{m}$ soil layer; root depth index $(R D I, \mathrm{~m})$ was measured using the whole root length found in soil depths of $0-2.0 \mathrm{~m}$; root weight $\left(R W, \mathrm{~g} \cdot \mathrm{m}^{-2}\right)$, and root length $\left(R L, \mathrm{~km} \cdot \mathrm{m}^{-2}\right)$ were measured per square meter; shoot weight was measured per square meter $\left(S W, g^{\prime} \cdot \mathbf{m}^{-2}\right)$; plant height $(H e i g h t, m)$ and stem number were measured per hill $($ Stem, hill $\left.{ }^{-1}\right)$.

\begin{tabular}{|c|c|c|c|c|c|c|c|c|c|c|}
\hline \multirow{3}{*}{ Site } & \multirow{3}{*}{$\begin{array}{c}\text { Plant } \\
\text { (months after } \\
\text { planting) }\end{array}$} & \multicolumn{5}{|c|}{ Root } & \multirow{3}{*}{$\begin{array}{c}R L \\
\left(\mathrm{~km} \cdot \mathrm{m}^{-2}\right)\end{array}$} & \multicolumn{3}{|c|}{ Shoot } \\
\hline & & \multicolumn{3}{|c|}{ Density } & \multirow{2}{*}{$\begin{array}{l}R D I \\
(\mathrm{~m})\end{array}$} & \multirow{2}{*}{$\begin{array}{c}R W \\
\left(\mathrm{~g} \cdot \mathrm{m}^{-2}\right)\end{array}$} & & \multirow{2}{*}{$\begin{array}{c}S W \\
\left(\mathrm{~g} \cdot \mathrm{m}^{-2}\right)\end{array}$} & \multirow{2}{*}{$\begin{array}{l}\text { Height } \\
\text { (m) }\end{array}$} & \multirow{2}{*}{$\begin{array}{c}\text { Stem } \\
\left(\text { hill }^{-1}\right)\end{array}$} \\
\hline & & Depth (m) & $R W D\left(\mathrm{~g} \cdot \mathrm{m}^{-3}\right)$ & $R L D\left(\mathrm{~km} \cdot \mathrm{m}^{-3}\right)$ & & & & & & \\
\hline \multirow{24}{*}{$\begin{array}{l}\text { Field } \\
\text { (Tokyo) }\end{array}$} & \multirow{6}{*}{$\begin{array}{c}\mathrm{Er} \\
(33)\end{array}$} & $0-0.4$ & 694 & 34.0 & \multirow{6}{*}{0.79} & \multirow{6}{*}{657} & \multirow{6}{*}{35.8} & \multirow{6}{*}{ n.a. } & \multirow{6}{*}{ n.a. } & \multirow{6}{*}{224.3} \\
\hline & & $0.4-0.8$ & 387 & 16.0 & & & & & & \\
\hline & & $0.8-1.2$ & 227 & 11.7 & & & & & & \\
\hline & & $1.2-1.6$ & 165 & 13.7 & & & & & & \\
\hline & & $1.6-2.0$ & 169 & 14.2 & & & & & & \\
\hline & & $2.0-2.6$ & 34 & 4.3 & & & & & & \\
\hline & \multirow{6}{*}{$\begin{array}{c}\mathrm{Er} \\
(13)\end{array}$} & $0-0.4$ & 432 & 40.9 & \multirow{6}{*}{0.40} & \multirow{6}{*}{384} & \multirow{6}{*}{28.8} & \multirow{6}{*}{ n.a. } & & \\
\hline & & $0.4-0.8$ & 243 & 11.1 & & & & & & \\
\hline & & $0.8-1.2$ & 175 & 8.9 & & & & & 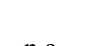 & 124 \\
\hline & & $1.2-1.6$ & 55 & 5.2 & & & & & II.a. & 124.2 \\
\hline & & $1.6-2.0$ & 56 & 6.1 & & & & & & \\
\hline & & $2.0-2.6$ & n.a & n.a & & & & & & \\
\hline & & $0-0.4$ & 264 & 37.1 & & & & & & \\
\hline & & $0.4-0.8$ & 62 & 10.1 & & & & & & \\
\hline & $\mathrm{Na}$ & $0.8-1.2$ & 49 & 9.4 & 047 & 183 & 203 & n & $n_{2}$ & 125 \\
\hline & (13) & $1.2-1.6$ & 47 & 8.8 & & & & & & \\
\hline & & $1.6-2.0$ & 37 & 7.9 & & & & & & \\
\hline & & $2.0-2.6$ & n.a & n.a & & & & & & \\
\hline & & $0-0.4$ & 233 & 17.7 & & & & & & \\
\hline & & $0.4-0.8$ & 88 & 6.7 & & & & & & \\
\hline & $\mathrm{Su}$ & $0.8-1.2$ & 23 & 4.0 & 0 & $1-0$ & 14 & & & 8 \\
\hline & (13) & $1.2-1.6$ & 35 & 4.3 & 0.48 & 158 & 14.6 & n.a. & n.a. & 3.2 \\
\hline & & $1.6-2.0$ & 15 & 3.7 & & & & & & \\
\hline & & $2.0-2.6$ & n.a & n.a & & & & & & \\
\hline & & $0-0.4$ & 1,121 & 60.8 & & & & & & \\
\hline & & $0.4-0.8$ & 440 & 8.5 & & & & & & \\
\hline & $\mathrm{Er}$ & $0.8-1.2$ & 284 & 3.8 & ก & $0=0$ & 201 & 1517 & 27 & 617 \\
\hline & (28) & $1.2-1.6$ & 160 & 3.7 & 0.34 & 000 & 31.0 & IJו & 3.1 & 01.5 \\
\hline & & $1.6-2.0$ & 120 & 2.2 & & & & & & \\
\hline Green house & & $2.0-2.6$ & 64 & 1.8 & & & & & & \\
\hline (Tokyo) & & $0-0.4$ & 566 & 93.6 & & & & & & \\
\hline & & $0.4-0.8$ & 86 & 6.0 & & & & & & \\
\hline & $\mathrm{Na}$ & $0.8-1.2$ & 69 & 3.2 & 0.24 & 334 & 43.6 & 2678 & 4.6 & 7.8 \\
\hline & & $1.2-1.6$ & 53 & 3.6 & & & & & & \\
\hline & & $1.6-2.0$ & 60 & 2.7 & & & & & & \\
\hline & & $2.0-2.6$ & 62 & 2.9 & & & & & & \\
\hline
\end{tabular}


Continued

\begin{tabular}{|c|c|c|c|c|c|c|c|c|c|c|}
\hline \multirow{6}{*}{ Field (Lampung) } & \multirow{6}{*}{$\begin{array}{c}\mathrm{Na} \\
(28)\end{array}$} & $0-0.4$ & 460 & 19.9 & \multirow{6}{*}{0.73} & \multirow{6}{*}{448} & \multirow{6}{*}{15.6} & \multirow{6}{*}{1669} & \multirow{6}{*}{3.1} & \multirow{6}{*}{10.0} \\
\hline & & $0.4-0.8$ & 176 & 5.3 & & & & & & \\
\hline & & $0.8-1.2$ & 169 & 4.9 & & & & & & \\
\hline & & $1.2-1.6$ & 153 & 4.0 & & & & & & \\
\hline & & $1.6-2.0$ & 163 & 4.8 & & & & & & \\
\hline & & $2.0-2.6$ & 34 & 0.9 & & & & & & \\
\hline
\end{tabular}

The extensiveness of the Erianthus and Napier grass root systems was confirmed from $R W$ and $R L$ values (Table 2). Erianthus had a root mass and root length of $384-850 \mathrm{~g} \cdot \mathrm{m}^{-2}$ and $28.8-35.8 \mathrm{~km} \cdot \mathrm{m}^{-2}$, respectively. In comparison, the values for Napier grass were 183 - 448 $\mathrm{g} \cdot \mathrm{m}^{-2}$ and $15.6-43.6 \mathrm{~km} \cdot \mathrm{m}^{-2}$, respectively. These values were much larger than those obtained for sugarcane, namely $158 \mathrm{~g}$ or $14.6 \mathrm{~km}$, respectively. Gregory (2006) [33] reviewed previous studies and summarized the maximum $R W$ and $R L$ recorded for 18 common crop species. While wheat had an exceptionally large $R W$ value of $350 \mathrm{~g} \cdot \mathrm{m}^{-2}$, the other crop species had low values, ranging from 25.5 to $166 \mathrm{~g} \cdot \mathrm{m}^{-2}$, which were well below the $R W$ values of Erianthus and Napier grass. Some crop species recorded relatively high $R L$ values, such as 26.5 $\mathrm{km} \mathrm{m} \mathrm{m}^{-2}$ in sorghum, $18.5-23.5 \mathrm{~km} \cdot \mathrm{m}^{-2}$ in wheat, 17.5 $\mathrm{km} \mathrm{m}{ }^{-2}$ in subterranean clover, and $15.1 \mathrm{~km} \cdot \mathrm{m}^{-2}$ in maize, which are comparable to the $R L$ values of Napier grass, but well below those of Erianthus.

Lemus and Lal (2005) [34] argue that the removal of aboveground biomass of energy plants might have little influence on soil organic carbon (SOC) due to their large belowground biomass. Indeed, Ma et al. (2000) [35] reported large $R W$ values of $1,500-3,633 \mathrm{~g} \cdot \mathrm{m}^{-2}$ for switchgrass. The authors concluded in a different report that switchgrass increases SOC several years after establishment [36]. These previous reports indicate that Erianthus and Napier grass might also have limited influence on $\mathrm{SOC}$, but that more time might be required for SOC to increase compared to switchgrass. This phenomenon requires clarification.

\section{Conclusion}

The current study confirmed that Erianthus and Napier grass develop deep root systems that penetrate to soil depths of $2.0-2.6 \mathrm{~m}$. The root mass and length of both species are large compared to common crop species. This indicates that quantities of associated exudates and dead roots would also be produced. Therefore, it is necessary to quantify the amount of dead roots and exudates that are produced, to further evaluate the capacity of these 2 species in sustaining soil fertility.

\section{Acknowledgements}

This study was financially supported by the New Energy and Industrial Technology Development Organization (NEDO). Erianthus seedlings were provided by M. Gau and N. Uwatoko of Kyushu Okinawa Agricultural Research Center, Japan. We are grateful to T. Hayashi, Y. Ichizawa, C. Tanaka, M. Nakashima, and Y. Izawa for the provision of root measurements, and to the Department of Technical Development of ISAS and TBI staff for their support with trench construction.

\section{REFERENCES}

[1] T. Hattori and S. Morita, "Energy Crops for Sustainable Bioethanol Production; Which, Where and How?" Plant Production Science, Vol. 13, No. 3, 2010, pp. 221-234. http://dx.doi.org/10.1626/pps.13.221

[2] R. M. Cruse, M. J. Cruse and D. C. Reicosky, "Soil Quality Impacts of Residue Removal for Biofuel Feedstock," In: R. Lal and B. A. Stewart, Eds., Soil Quality and Biofuel Production, CRC Press, New York, 2010, pp. 45-62.

[3] T. Hattori, F. Shiotsu, T. Doi and S. Morita, "Suppression of Tillering in Erianthus ravennae (L.) Beauv. Due to Drought Stress at Establishment," Plant Production Science, Vol. 13, No. 3, 2010, pp. 252-255. http://dx.doi.org/10.1626/pps.13.252

[4] K. Ra, F. Shiotsu, J. Abe and S. Morita, "Biomass Yield and Nitrogen Use Efficiency of Cellulosic Energy Crops for Ethanol Production," Biomass and Bioenergy, Vol. 37, 2012, pp. 330-334. http://dx.doi.org/10.1016/j.biombioe.2011.12.047

[5] Y. Kuzyakov and G. Domanski, "Carbon Input by Plants Into the Soil. Review," Journal of Plant Nutrition and Soil Science, Vol. 163, No. 4, 2000, pp. 421-431. http://dx.doi.org/10.1002/1522-2624(200008)163:4<421:: AID-JPLN421>3.0.CO;2-R

[6] J. Farrar, M. Hawes, D. Jones and S. Lindow, "How Roots Control the Flux of Carbon to the Rhizosphere," Ecology, Vol. 84, No. 4, 2003, pp. 827-837. http://dx.doi.org/10.1890/0012-9658(2003)084[0827:HR CTFO]2.0.CO;2

[7] B. Steingrobe, H. Schmid and N. Claassen, "Root Production and Root Mortality of Winter Barley and Its Implication with Regard to Phosphorus Acquisition," Plant and Soil, Vol. 237, No. 2, 2001, pp. 239-248. 
http://dx.doi.org/10.1023/A:1013345718414

[8] B. Steingrobe, H. Schmid, R. Guster and N. Claassen, "Root Production and Root Mortality of Winter Wheat Grown on Sandy and Loamy Soils in Different Farming Systems," Biology and Fertility of Soils, Vol. 33, No. 4, 2001, pp. 331-339.

http://dx.doi.org/10.1007/s003740000334

[9] N. Sekiya, T. Hattori, F. Shiotsu, J. Abe and S. Morita, "Identifying Potential Field Sites for Production of Cellulosic Energy Plants," (Unpublished).

[10] A. Oyanagi, T. Nakamoto and M. Wada, "Relationship between Root Growth Angle of Seedlings and Vertical Distribution of Roots in the Field in Wheat Cultivars," Japanese Journal of Crop Science, Vol. 62, No. 4, 1993, pp. 565-570. http://dx.doi.org/10.1626/jcs.62.565

[11] P. Jackson and R. J. Henry, "Erianthus," In: C. Kole, Ed., Wild Crop Relatives: Genomic and Breeding Resources, Springer, Berlin, 2011, pp. 97-107. http://dx.doi.org/10.1007/978-3-642-21102-7 5

[12] S. C. Tiwari, "Variations in Net Primary Production of Garhwal Himalayan Grasslands," Tropical Ecology, Vol. 27, No. 2, 1986, pp. 166-173.

[13] G. Farrell, S. A. Simons and R. J. Hillocks, "Pests, Disease and Weeds of Napier Grass, Pennisetum purpureum: A Review," International Journal of Pest Management, Vol. 48, No. 1, 2002, pp. 39-48. http://dx.doi.org/10.1080/09670870110065578

[14] S. D. Angima, D. E. Stott, M. K. O’Neill, C. K. Ong and G. A. Weesies, "Use of Calliandra-Napier Grass Hedges to Control Erosion in Central Kenya," Agriculture, Ecosystems \& Environments, Vol. 91, No. 1-3, 2002, pp. 1523. http://dx.doi.org/10.1016/S0167-8809(01)00268-7

[15] J. K. Mutegi, D. N. Mugendi, L. V. Verchot and J. M. Kung'u, "Combining Napier Grass with Leguminous Shrubs in Contour Hedgerows Controls Soil Erosion without Competing with Crops," Agroforestry Systems, Vol. 74, No. 1, 2008, pp. 37-49.

http://dx.doi.org/10.1007/s10457-008-9152-3

[16] A. B. Orodho, "The Role and Importance of Napier Grass in the Smallholder Dairy Industry in Kenya," 2006. http://www.fao.org/ag/agp/agpc/doc/Newpub/napier/napi er_kenya.htm

[17] C. Ma, R. Naidu, F. Liu, C. Lin and H. Ming, "Influence of Hybrid Giant Napier Grass on Salt and Nutrient Distribution with Depth in a Saline Soil," Biodegradation, Vol. 23, No. 6, 2012, pp. 907-916.

http://dx.doi.org/10.1007/s10532-012-9583-4

[18] J. E. Knoll, W. F. Anderson, T. C. Strickland, R. K. Hubbard and R. Malik, "Low-Input Production of Biomass from Perennial Grasses in the Coastal Plain of Georgia, USA," Bioenergy Research, Vol. 5, No. 1, 2012, pp. 206-214.

http://dx.doi.org/10.1007/s12155-011-9122-x

[19] A. Oyanagi, "Gravitropic Response Growth Angle and Vertical Distribution of Roots of Wheat (Triticum aestivum L.)," Plant and Soil, Vol. 165, No. 2, 1994, pp. 323326. http://dx.doi.org/10.1007/BF00008076

[20] S.-H. Cheng, L.-Y. Cao, J.-Y. Zhuang, W.-M. Wu, S.-H.
Yang and X.-D. Zhan, "A Breeding Strategy for Hybrid Rice in China," In: F. Xie andB. Hardy, Eds., Accelerating Hybrid Rice Development, IRRI, Manila, 2009, pp. 25-34.

[21] Y. Izumi, K. Uchida and M. Iijima, "Crop Production in Successive Wheat-Soybean Rotation with No Tillage Practice in Relation to the Root System Development," Plant Production Science, Vol. 7, No. 3, 2004, pp. 329336. http://dx.doi.org/10.1626/pps.7.329

[22] Y. Fukuzawa, Y. Komiya, M. Ueno and Y. Kawamitsu, "Relationship between the Development of the Root System and Initial Growth of Sugarcane (in Japanese with English Abstract)," Japanese Journal of Crop Science, Vol. 78, No. 3, 2009, pp. 356-362. http://dx.doi.org/10.1626/jcs.78.356

[23] A. Oyanagi, T. Nakamoto and M. Wada, "How Deep Should We Measure Root Length to Find a Varietal Difference of Root Distribution in Wheat?" In: J. E. Box, Ed., Root Demographics and Their Efficiencies in Sustainable Agriculture, Grasslands and Forest Ecosystems, Kluwer Academic Publisher, Dordrecht, 1998, pp. 789-793. http://dx.doi.org/10.1007/978-94-011-5270-9 68

[24] P. J. Gregory, M. McGowan, P. V. Biscoe and B. Hunter, "Water Relations of Winter Wheat: 1. Growth of the Root System," The Journal of Agricultural Science, Vol. 91, No. 1, 1978, pp. 91-102. http://dx.doi.org/10.1017/S0021859600056653

[25] F. Wiesler and W. J. Horst, "Root Growth and Nitrate Utilization of Maize Cultivation under Field Conditions," Plant and Soil, Vol. 163, No. 2, 1994, pp. 267-277. http://dx.doi.org/10.1007/BF00007976

[26] R. J. K. Myers, "The Root System of a Grain Sorghum Crop," Field Crops Research, Vol. 3, 1980, pp. 53-64. http://dx.doi.org/10.1016/0378-4290(80)90007-6

[27] M. Kondo, M. V. R. Murty and D. V. Aragones, "Characteristics of Root Growth and Water Uptake from sOil in Upland Rice and Maize under Water Stress," Soil Science and Plant Nutrition, Vol. 46, No. 3, 2000, pp. 721-732. http://dx.doi.org/10.1080/00380768.2000.10409137

[28] B. Ball-Coelho, E. V. S. V. Sampaio, H. Tiessen and J. W. B. Stewart, "Root Dynamics in Plant and Ratoon Crops of Sugar Cane," Plant and Soil, Vol. 142, No. 2, 1992, pp. 297-305. http://dx.doi.org/10.1007/BF00010975

[29] P. B. Laclau and J. P. Laclau, "Growth of the Whole Root System for a Plant Crop of Sugarcane under Rainfed and Irrigated Environment in Brazil," Field Crops Research, Vol. 114, No. 3, 2009, 351-360. http://dx.doi.org/10.1016/j.fcr.2009.09.004

[30] P. B. Barraclough, "Root Growth, Macro-Nutrient Uptake Dynamics and Soil Fertility Requirements of a HighYielding Winter Oilseed Rape Crop," Plant and Soil, Vol. 119, No. 1, 1989, pp. 59-70. http://dx.doi.org/10.1007/BF02370269

[31] M. V. K. Sivakumar, H. M. Taylor and R. H. Shaw, “Top and Root Relations of Field-Grown Soybean," Agronomy Journal, Vol. 69, No. 3, 1977, pp. 470-473.

http://dx.doi.org/10.2134/agronj1977.0002196200690003 $\underline{0034 \mathrm{x}}$

[32] B. Klepper, H. M. Taylor, M. G. Huck and E. L. Fiscus, 
"Water Relations and Growth of Cotton in Drying Soil," Agronomy Journal, Vol. 65, No. 2, 1973, pp. 307-310. http://dx.doi.org/10.2134/agronj1973.0002196200650002 $\underline{0036 x}$

[33] P. J. Gregory, "Plant Roots: Their Growth, Activity, and Interaction with Soils," Blackwell, Oxford, 2006.

[34] R. Lemus and R. Lal, "Bioenergy Crops and Carbon Sequestration," Critical Reviews in Plant Science, Vol. 24, No. 1, 2005, pp. 1-21. http://dx.doi.org/10.1080/07352680590910393
[35] Z. Ma, C. W. Wood and D. I. Bransby, "Impacts of Soil Management on Root Characteristics of Switchgrass," Biomass and Bioenergy, Vol. 18, No. 2, 2000, pp. 105112. http://dx.doi.org/10.1016/S0961-9534(99)00076-8

[36] Z. Ma, C. W. Wood and D. I. Bransby, "Soil Management Impact on Soil Carbon Sequestration by Switchgrass," Biomass and Bioenergy, Vol. 18, No. 1, 2000, pp. 469-477.

http://dx.doi.org/10.1016/S0961-9534(00)00013-1 